Check for updates

Cite this: RSC Adv., 2017, 7, 35403

\title{
Molecular dynamics simulation of low-energy recoil events in titanate pyrochlores
}

\begin{abstract}
Liyuan Dong, ${ }^{a}$ Wahyu Setyawan, ${ }^{\text {b }}$ Yuhong Li, ${ }^{* a}$ Ram Devanathan*b and Fei Gao (D) *c
Molecular dynamics simulations of low-energy displacement events in titanate pyrochlores $\mathrm{A}_{2} \mathrm{Ti}_{2} \mathrm{O}_{7}(\mathrm{~A}=\mathrm{Lu}$, $\mathrm{Er}, \mathrm{Gd}, \mathrm{Eu}, \mathrm{Ce}, \mathrm{La})$ have been carried out along three main crystallographic directions, [100], [110] and [111], to determine threshold displacement energies $\left(E_{d}\right)$ for $\mathrm{A}$, Ti and $\mathrm{O}$, corresponding defect configurations, and defect formation dynamics. The A-site cation size was found to have an important effect on the value of $E_{d}$ for each type of ion in titanate pyrochlores. $E_{\mathrm{d}}$ depended on the knock-on direction, ion type, and Wyckoff position ( $48 \mathrm{f} v \mathrm{vs}$. $8 \mathrm{~b}$ site for $\mathrm{O}$ ). The influence of $\mathrm{A}$-site cation size on $E_{\mathrm{d}}$ for $\mathrm{Ti}$ and $\mathrm{O}_{48 \mathrm{f}}$ was significantly larger than on $E_{d}$ for $A$ and $O_{8 b}$ in titanate pyrochlores. Besides, the value of $E_{d}$ for each type of atom in titanate pyrochlores was highly anisotropic. The largest change of $E_{d}$ was for Ti, while the smallest change of $E_{d}$ was for $\mathrm{O}_{8 b}$. The energy required to displace the $\mathrm{A}$ cation was less than that to displace $\mathrm{Ti}$. The lowest displacement energy was for the anion in titanate pyrochlores. The easiest displacement direction for $\mathrm{Ti}^{4+}$ and $\mathrm{O}_{48 f}$ was along [100], while the easiest directions for $\mathrm{A}^{3+}$ and $\mathrm{O}_{8 b}$ in titanate pyrochlores varied with the choice of A-site cation. Among the surviving defects, Frenkel pairs were dominant at the end of low-energy recoils. Cation displacements produced both cation and anion defects, while anion displacements produced only anion defects. Thus, cation displacement, which occurs at higher recoil energies, holds the key to amorphization. With increasing $A$-site cation radius in titanate pyrochlores $\mathrm{A}_{2} \mathrm{Ti}_{2} \mathrm{O}_{7}(\mathrm{~A}=\mathrm{Lu}, \mathrm{Er}, \mathrm{Gd}, \mathrm{Eu})$, the variation of the $E_{d}$ of Ti along [110] was similar to the variation of the experimental critical amorphization temperature $\left(T_{c}\right)$. The displacement of Ti along [110] may play an important role in the amorphization of titanate pyrochlores.
\end{abstract}

Received 26th April 2017

Accepted 8th July 2017

DOI: $10.1039 / c 7 r a 04699 e$

rsc.li/rsc-advances containing large A-site cations and smaller B-site cations, and the ratio of radii of A-site and B-site cations can play a key role in the order-disorder (O-D) transformation, amorphization tolerance, and radiation resistance. Lian et al. ${ }^{14,19}$ investigated the amorphization resistance of titanate pyrochlores $\mathrm{A}_{2} \mathrm{Ti}_{2} \mathrm{O}_{7}(\mathrm{~A}=$ $\mathrm{Sm}, \mathrm{Eu}, \mathrm{Gd}, \mathrm{Dy}, \mathrm{Lu}, \mathrm{Y})$ irradiated by $1.0 \mathrm{MeV} \mathrm{Kr}^{+}$. The results indicated that $\mathrm{Gd}_{2} \mathrm{Ti}_{2} \mathrm{O}_{7}$ is more sensitive to radiation damage than other titanate pyrochlores, suggesting that A-site cations have an effect on the resistance of amorphization. Wang et al. ${ }^{20}$ studied the critical amorphization temperatures $\left(T_{\mathrm{c}}\right)$ in titanate pyrochlores $\left(\mathrm{A}_{2} \mathrm{Ti}_{2} \mathrm{O}_{7}, \mathrm{~A}=\mathrm{Gd}, \mathrm{Sm}, \mathrm{Eu}, \mathrm{Y}\right)$ by using $1 \mathrm{MeV} \mathrm{Kr}^{+}$ irradiation. $T_{\mathrm{c}}$ is the temperature above which radiation by energetic particles cannot amorphize the material. The results indicated that $\mathrm{Gd}_{2} \mathrm{Ti}_{2} \mathrm{O}_{7}$ had the highest $T_{\mathrm{c}} \approx 1100 \mathrm{~K}$ and that the critical dose for irradiation-induced amorphization varied with different lanthanides occupying the A-site. Meanwhile, Begg et al. ${ }^{21}$ investigated $T_{\mathrm{c}}$ for $\mathrm{A}_{2} \mathrm{Ti}_{2} \mathrm{O}_{7}(\mathrm{~A}=\mathrm{Y}, \mathrm{Sm}, \mathrm{Gd}, \mathrm{Lu})$ by using $600 \mathrm{keV} \mathrm{Bi}^{+}$, and suggested that there are no significant effects of A-site cations on the resistance of titanate pyrochlores to ion-beam induced amorphization. Molecular statics studies by Minervini $e t a l .{ }^{18}$ revealed that the cation disorder increases with the increasing cation radius ratio: $r_{\mathrm{B}} / r_{\mathrm{A}}$. Molecular dynamics (MD) simulations by Devanathan et al..$^{17,22}$ showed that cation choice in pyrochlores can affect the radiation

\footnotetext{
${ }^{a}$ School of Nuclear Science and Technology, Lanzhou University, Lanzhou, Gansu 730000, China.E-mail: liyuhong@lzu.edu.cn

${ }^{b}$ Energy and Environment Directorate, Pacific Northwest National Laboratory, Richland, WA 99352, USA. E-mail: ram.devanathan@pnnl.gov

${ }^{c}$ Department of Nuclear Engineering \& Radiological Sciences, University of Michigan, Ann Arbor, MI 48109, USA. E-mail: gaofeium@umich.edu
} 
tolerance, amorphization resistance, O-D transformation, and volume swelling. A modeling study by Xiao et $a{ }^{23}{ }^{23}$ indicated that the A-site cation has an important effect on the defect production mechanism, and that oxygen migration from $\mathrm{O}_{48 f}$ and $\mathrm{O}_{8 b}$ sites to $\mathrm{O}_{8 a}$ sites is dominant under low-energy irradiation. It is evident that chemical composition especially the choice of cations can affect the radiation response of pyrochlores. However, there are still considerable gaps in our understanding of the influence of A-site cation size on defect production by low-energy recoil events that occur near the end of range of energetic recoils in titanate pyrochlores. The present work addresses this need.

The threshold displacement energy $\left(E_{\mathrm{d}}\right)$ is a fundamental parameter needed to quantify displacements and defect production under energetic particle irradiation. $E_{\mathrm{d}}$ represents the energy needed to displace an atom to produce a stable defect on its own sublattice. $E_{\mathrm{d}}$ can be measured in experiments by using optical and thermally stimulated spectroscopies, electron paramagnetic resonance, positron annihilation, and electron microscopy. ${ }^{24-27}$ However, measuring $E_{\mathrm{d}}$ experimentally is still a challenging task. Furthermore, it is very difficult to study experimentally the details of displacement processes that occur in very short time and small length scales, or to distinguish the dynamic defect formation processes for each sublattice. Consequently, the experimental determination for $E_{\mathrm{d}}$ in ceramics is more difficult than in metals since ceramics usually consist of multiple sublattices. For pyrochlore compounds, only the threshold displacement energies for $\mathrm{O}$ sublattice in $\mathrm{La}_{2} \mathrm{Zr}_{2} \mathrm{O}_{7}$ are available in the literature. ${ }^{28}$ Theoretically, $E_{\mathrm{d}}$ can be calculated by the sudden approximation (SA) method $^{\mathbf{2 4 , 2 9}}$ or by the MD method. However, the SA method only relaxes the system by energy minimization, and does not consider the dynamic effect of the primary knock-on atom (PKA) or the mass ratio effect (heavier $v s$. lighter ions) during collision cascades. On the other hand, MD is ideal to simulate the dynamic collision process and the mass effect is inherently included. MD has been successfully used to determine the $E_{\mathrm{d}}$ in a variety of materials, such as $\alpha-\mathrm{Fe},{ }^{30,31} \mathrm{FeCr},{ }^{32} \mathrm{TiO}_{2},{ }^{33}$ and $\mathrm{ZrSiO}_{4} \cdot{ }^{34}$ Devanathan et al. ${ }^{22}$ calculated $E_{\mathrm{d}}$ in $\mathrm{Gd}_{2} \mathrm{Zr}_{2} \mathrm{O}_{7}$ and $\mathrm{Gd}_{2} \mathrm{Ti}_{2} \mathrm{O}_{7}$ along 9 crystallographic directions with $\mathrm{MD}$ and suggested that greater ease of anion disorder, lower energy penalty for cation disorder, and faster ionic diffusion result in greater amorphization resistance. Xiao et al. ${ }^{35}$ and Gao et al. ${ }^{36}$ calculated $E_{\mathrm{d}}$ in $\mathrm{Y}_{2} \mathrm{Ti}_{2} \mathrm{O}_{7}$ using $a b$ initio MD (AIMD), and indicated that the relative stability of cation interstitials may provide a pathway for driving irradiation-induced amorphization. Wang et al. ${ }^{37}$ calculated $E_{\mathrm{d}}$ in $\mathrm{Gd}_{2} \mathrm{Zr}_{2} \mathrm{O}_{7}$ and $\mathrm{Gd}_{2} \mathrm{Ti}_{2} \mathrm{O}_{7}$ by AIMD method, and revealed that anion order-disorder is more likely to be involved in the displacement than cation disordering. Although previous work has shed light on understanding the low-energy recoils and defect production process of certain pyrochlores, there have been few studies on the effects of cation choice on defect production in titanate pyrochlores. Therefore, the main purpose of this work is to investigate $E_{\mathrm{d}}$ and the defects produced during low energy displacement events in titanate pyrochlores.
In the current work, MD simulations have been employed to investigate the low-energy displacement events for each type of atom for 6 different chemical compositions of titanate pyrochlores $\mathrm{A}_{2} \mathrm{Ti}_{2} \mathrm{O}_{7}\left(\mathrm{~A}^{3+}=\mathrm{Lu}^{3+}, \mathrm{Er}^{3+}, \mathrm{Gd}^{3+}, \mathrm{Eu}^{3+}, \mathrm{Ce}^{3+}, \mathrm{La}^{3+}\right)$ along three crystallographic directions, namely [100], [110] and [111]. Since [100], [110] and [111] directions are major crystallographic orientations in the pyrochlore structure, these directions are the most studied in the previous studies. The aims are (1) to determine threshold displacement energies for all three sublattices in titanate pyrochlores along specific knock-on directions, (2) to obtain a fundamental insight into the defect formation process, and (3) to compare the response of the lattice to low-energy displacement events for each pyrochlore composition. The minimum value of $E_{\mathrm{d}}$ for each type of ion in titanate pyrochlore and corresponding directions have been determined. The values of $E_{\mathrm{d}}$ obtained in the current work can be used as input for binary collision Monte Carlo codes, such as TRIM $^{38}$ and SRIM, ${ }^{39}$ to estimate displacement damage accumulation caused by electron, ion, or neutron irradiation, and provide a means to determine the damage dose in displacements per atom for ion-beam irradiation experiments. Since the system considered by TRIM/SRIM is anisotropic, the average value of $E_{\mathrm{d}}$ for all the directions simulated can be used as input for TRIM and SRIM. The simulations also provide details on the type of defects produced and the mechanism of defect production by low energy recoils.

\section{Computational details}

Titanate pyrochlore, with a general formula of $\mathrm{A}_{2} \mathrm{Ti}_{2} \mathrm{O}_{7}(\mathrm{~A}=$ rare earth elements), has a cubic structure as illustrated in Fig. 1. The unit cell $(F d \overline{3} \mathrm{~m} / 227 \text { space group })^{40}$ includes 8 formula units $(Z=8)$, containing 88 ions: $16 \mathrm{~A}^{3+}$ cations, $16 \mathrm{Ti}^{4+}$ cations and $56 \mathrm{O}^{2-}$ anions. The $\mathrm{A}^{3+}$ cations occupy the Wyckoff position $16 \mathrm{~d}$

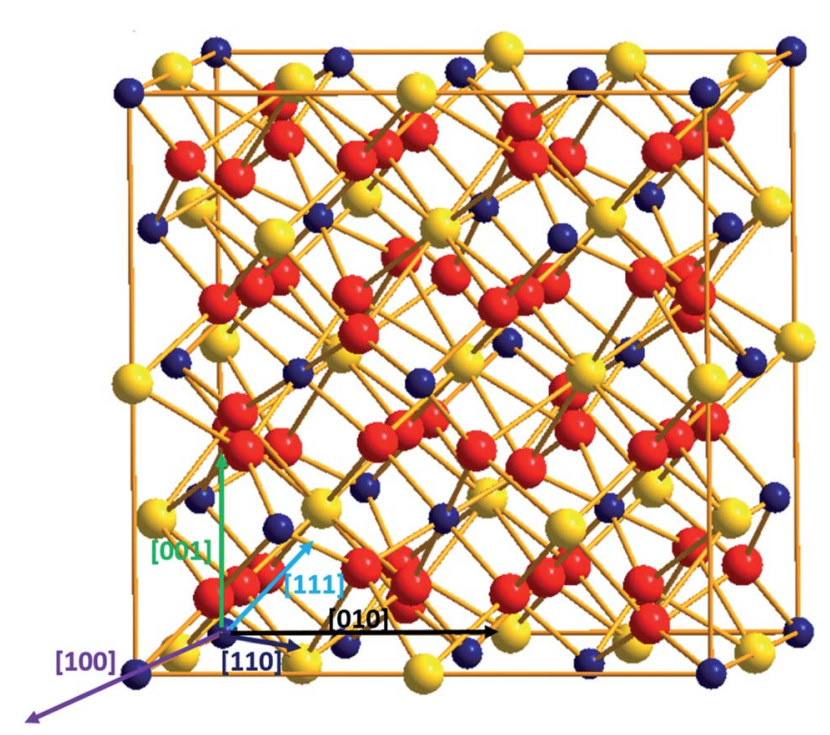

Fig. 1 Titanate pyrochlores $\mathrm{A}_{2} \mathrm{Ti}_{2} \mathrm{O}_{7}$ structure: yellow sphere represents the A-site cations; blue sphere represents Ti cations; red sphere stands for $\mathrm{O}$ anions. 
$(1 / 2,1 / 2,1 / 2)$, the $\mathrm{Ti}^{4+}$ cations are at the $16 c(0,0,0)$ position, and the $\mathrm{O}^{2-}$ anions are at the $8 b(3 / 8,3 / 8,3 / 8)$ and $48 f(x, 1 / 8,1 / 8)$ positions. Geometrically, A-site cations (with atomic radius of $\sim 100 \mathrm{pm}$ ) are eight-coordinated surrounded by six $\mathrm{O}_{48 f}$ and two $\mathrm{O}_{8 b}$, while $\mathrm{Ti}$ cations (atomic radius of $60.5 \mathrm{pm}$ ) are sixcoordinated and surrounded by six $\mathrm{O}_{48 f}$ anions.

A combination of long-range columbic potential with formal charges ( +3 for A cation, +4 for $\mathrm{Ti}$, and -2 for $\mathrm{O}$ ) and modified short-range Buckingham potential was employed to describe the ionic interactions. The smooth particle mesh Ewald summation $^{41}$ was used to calculate the electrostatic interactions with a cut off radius of $10 \AA$ and tolerance of $10^{-8}$. To provide effective short-range potentials, the repulsive Ziegler-BiersackLittmark (ZBL) potentials were used in the very short range and were smoothly joined to the Buckingham potentials by using exponential functions. The potential parameters have been described in detail elsewhere. ${ }^{\mathbf{1 8 4 2}}$ According to the previous studies, ${ }^{\mathbf{1 8 , 4 2}}$ these potentials can provide reasonable matches between the defect formation energies and static properties (such as lattice parameter, bulk modulus, and thermal properties) and the corresponding experimental measurements over a wide composition range, which validates these potentials for simulation of the effects of A-site cation and the dynamics of low-energy recoils in titanate pyrochlores.

The MD simulations were performed using the LAMMPS (Large-scale Atomic/Molecular Massively Parallel Simulator) code, ${ }^{43}$ which was developed at Sandia National Laboratory, USA. The simulation cell contained $3 \times 3 \times 3$ unit cells and 2376 atoms with the side length of the cube being $\sim 30 \AA$. Periodic boundary conditions were employed. All simulations were performed with a time step of 0.5 fs. Before the low-energy cascade was simulated, the system was equilibrated at zero external pressure with constant number of atoms, pressure and temperature (NPT ensemble) for $15 \mathrm{ps}$ at a temperature of $10 \mathrm{~K}$. Using the equilibrated configuration, displacements were simulated with constant number of atoms, volume and energy (NVE ensemble) and the evolution of the system was followed for $4 \mathrm{ps}$. Three simulations were performed to determine $E_{\mathrm{d}}$ for $\mathrm{A}, \mathrm{Ti}, \mathrm{O}_{48 f}$ and $\mathrm{O}_{8 b}$ along each direction to evaluate the statistical effects, and only the smallest value is reported here.

$E_{\mathrm{d}}$ corresponds to the minimum energy to form stable defects, which were identified after 4 ps. For each simulation, the defects were detected by the Wigner-Seitz defect analysis ${ }^{\mathbf{4}}$ method. This method has been shown to be ideal for determining defects in crystalline materials ${ }^{45,46}$ including $\alpha$-Fe, SiC, semiconductors and oxides. For each type of atom in titanate pyrochlores, $E_{\mathrm{d}}$ was determined by running a series of simulations, with different kinetic energies imparted to a single primary knock-on atom (PKA) along a specific crystal direction. The initial PKA kinetic energy was $10 \mathrm{eV}$ and this energy was increased in steps of $10 \mathrm{eV}$ in subsequent simulations until a stable defect was created. Afterwards, the energy was decreased with a decrement of $1 \mathrm{eV}$ until no stable defect was created. The lowest energy at which a stable defect was created was taken as the $E_{\mathrm{d}}$ for the corresponding sublattice.

\section{Results and discussion}

\section{1 $E_{\mathrm{d}}$ in $\mathrm{A}_{2} \mathrm{Ti}_{2} \mathrm{O}_{7}$ pyrochlore along the [100] direction}

Fig. 2 shows the variation of $E_{\mathrm{d}}$ for $\mathrm{A}, \mathrm{Ti}, \mathrm{O}_{48 f}$ and $\mathrm{O}_{8 b}$ in titanate pyrochlores $\mathrm{A}_{2} \mathrm{Ti}_{2} \mathrm{O}_{7}\left(\mathrm{~A}^{3+}=\mathrm{Lu}^{3+}, \mathrm{Er}^{3+}, \mathrm{Gd}^{3+}, \mathrm{Eu}^{3+}, \mathrm{Ce}^{3+}, \mathrm{La}^{3+}\right)$ with increasing A-site cation radius along the crystallographic direction [100]. $E_{\mathrm{d}}$ for Ti decreased significantly from $172 \mathrm{eV}$ in $\mathrm{Lu}_{2} \mathrm{Ti}_{2} \mathrm{O}_{7}$ to $136 \mathrm{eV}$ in $\mathrm{La}_{2} \mathrm{Ti}_{2} \mathrm{O}_{7}$. In contrast, $E_{\mathrm{d}}$ for A-site cation, $\mathrm{O}_{48 f}$ and $\mathrm{O}_{8 b}$ remained almost unchanged with values of $69.5 \pm$ $1.5 \mathrm{eV}, 52.5 \pm 0.5 \mathrm{eV}$ and $55 \pm 2 \mathrm{eV}$, respectively. It should be mentioned that the value of $E_{\mathrm{d}}$ for Ce in $\mathrm{Ce}_{2} \mathrm{Ti}_{2} \mathrm{O}_{7}$ was $59 \mathrm{eV}$ along the [100] direction, which was much lower than $\sim 70 \mathrm{eV}$ for the A-site cation in the other titanate pyrochlores. This finding suggests that $\mathrm{Ce}_{2} \mathrm{Ti}_{2} \mathrm{O}_{7}$ may be more susceptible to displace along [100] direction than other titanate pyrochlores which may lead to differences in amorphization resistance of $\mathrm{Ce}_{2} \mathrm{Ti}_{2} \mathrm{O}_{7}$ compared to the other titanate pyrochlores. In addition, it's easier to displace the A-site cation than the Ti cation, and it requires less energy to displace anions than cations, which is consistent with the previous studies ${ }^{22,35-37}$ of titanate pyrochlores.

Table 1 lists defect end states for $\mathrm{A}, \mathrm{Ti}, \mathrm{O}_{48 f}$ and $\mathrm{O}_{8 b}$ in titanate pyrochlores after low-energy displacements along the knock-on direction [100]. The Kröger-Vink notation was used to

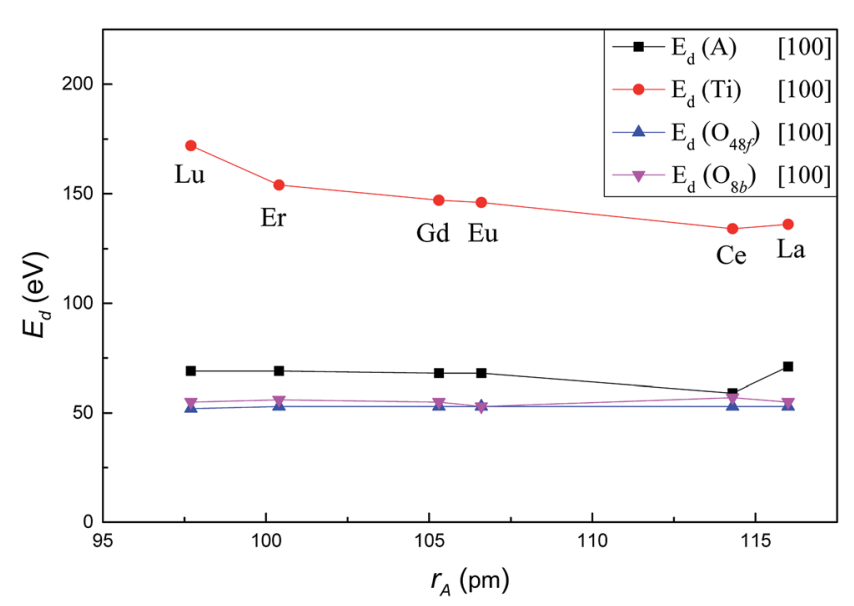

Fig. 2 Variation of $E_{d}$ value for $\mathrm{A}, \mathrm{Ti}, \mathrm{O}_{48 \mathrm{f}}$ and $\mathrm{O}_{8 \mathrm{~b}}$ in $\mathrm{A}_{2} \mathrm{Ti}_{2} \mathrm{O}_{7}$ as a function of $A$-site cation ionic radii along [100] crystallographic direction.

Table 1 Surviving defects after displacements for each type of atom in titanate pyrochlore along [100]

\begin{tabular}{|c|c|c|c|c|}
\hline & $\mathrm{A}$ & $\mathrm{Ti}$ & $\mathrm{O}_{48 f}$ & $\mathrm{O}_{8 b}$ \\
\hline Name & Defects & Defects & Defects & Defects \\
\hline $\mathrm{Lu}_{2} \mathrm{Ti}_{2} \mathrm{O}_{7}$ & $\mathrm{~V}_{\mathrm{Lu}} \mathrm{Ti}_{\mathrm{i}} \mathrm{Lu}_{\mathrm{Ti}}$ & $\mathrm{V}_{\mathrm{Lu}} \mathrm{Ti}_{\mathrm{i}} \mathrm{Lu}_{\mathrm{Ti}}$ & $\mathrm{V}_{\mathrm{O}} \mathrm{O}_{\mathrm{i}}$ & $\mathrm{V}_{\mathrm{O}} \mathrm{O}_{\mathrm{i}}$ \\
\hline $\mathrm{Er}_{2} \mathrm{Ti}_{2} \mathrm{O}_{7}$ & $\mathrm{~V}_{\mathrm{Er}} \mathrm{Ti}_{\mathrm{i}} \mathrm{Er}_{\mathrm{Ti}}$ & $\mathrm{V}_{\mathrm{Er}} \mathrm{Ti}_{\mathrm{i}} \mathrm{Er}_{\mathrm{Ti}}$ & $\mathrm{V}_{\mathrm{O}} \mathrm{O}_{\mathrm{i}}$ & $\mathrm{V}_{\mathrm{O}} \mathrm{O}_{\mathrm{i}}$ \\
\hline $\mathrm{Gd}_{2} \mathrm{Ti}_{2} \mathrm{O}_{7}$ & $\mathrm{~V}_{\mathrm{Gd}} \mathrm{Ti}_{\mathrm{i}} \mathrm{Gd}_{\mathrm{Ti}}$ & $\mathrm{V}_{\mathrm{Gd}} \mathrm{Ti}_{\mathrm{i}} \mathrm{Gd}_{\mathrm{Ti}}$ & $\mathrm{V}_{\mathrm{O}} \mathrm{O}_{\mathrm{i}}$ & $\mathrm{V}_{\mathrm{O}} \mathrm{O}_{\mathrm{i}}$ \\
\hline $\mathrm{Eu}_{2} \mathrm{Ti}_{2} \mathrm{O}_{7}$ & $\mathrm{~V}_{\mathrm{Eu}} \mathrm{Ti}_{\mathrm{i}} \mathrm{Eu}_{\mathrm{Ti}}$ & $\mathrm{V}_{\mathrm{Eu}} \mathrm{Ti}_{\mathrm{i}} \mathrm{Eu}_{\mathrm{Ti}}$ & $\mathrm{V}_{\mathrm{O}} \mathrm{O}_{\mathrm{i}}$ & $\mathrm{V}_{\mathrm{O}} \mathrm{O}_{\mathrm{i}}$ \\
\hline $\mathrm{Ce}_{2} \mathrm{Ti}_{2} \mathrm{O}_{7}$ & 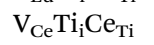 & $\mathrm{V}_{\mathrm{Ti}} \mathrm{Ce}_{\mathrm{i}} \mathrm{Ti}_{\mathrm{Ce}}$ & $\mathrm{V}_{\mathrm{O}} \mathrm{O}_{\mathrm{i}}$ & $\mathrm{V}_{\mathrm{O}} \mathrm{O}_{\mathrm{i}}$ \\
\hline $\mathrm{La}_{2} \mathrm{Ti}_{2} \mathrm{O}_{7}$ & $\mathrm{~V}_{\mathrm{La}} \mathrm{Ti}_{\mathrm{i}} \mathrm{La}_{\mathrm{Ti}}$ & $\mathrm{V}_{\mathrm{Ti}} 2 \mathrm{Ti}_{\mathrm{i}} \mathrm{V}_{\mathrm{La}} \mathrm{La}_{\mathrm{Ti}}$ & $\mathrm{V}_{\mathrm{O}} \mathrm{O}_{\mathrm{i}}$ & $\mathrm{V}_{\mathrm{O}} \mathrm{O}_{\mathrm{i}}$ \\
\hline
\end{tabular}


describe defects created after displacement. Namely, $\mathrm{V}_{\mathrm{A}}$ represents an A-site vacancy, $B_{i}$ represents a B-cation interstitial, and $A_{B}$ represents an antisite defect formed by an A-site cation on a B (Ti) site. When an A-site cation was displaced along [100], it encountered an adjacent Ti atom and occupied that site by displacing the $\mathrm{Ti}$ into an interstitial position. Therefore, the defects consisted of $\mathrm{a} \mathrm{V}_{\mathrm{A}}$, an $\mathrm{A}_{\mathrm{Ti}}$, and a $\mathrm{Ti}_{\mathrm{i}}$. The displacement process of a Ti PKA was more complex than that of an A-site cation. With Ti PKA, the formation of the expected $\mathrm{Ti}_{\mathrm{A}}$ antisite did not occur in most of the titanate pyrochlores $\left(\mathrm{A}_{2} \mathrm{Ti}_{2} \mathrm{O}_{7} ; \mathrm{A}=\right.$ $\mathrm{Lu}, \mathrm{Er}, \mathrm{Gd}, \mathrm{Eu})$. Instead, the Ti PKA returned to its lattice site, while the secondary knock-on atom (SKA) (A-site cation) underwent a characteristic A-site cation [100] displacement leading to an $\mathrm{A}_{\mathrm{Ti}}$ antisite defect. The A-site cation SKA recoil collided with a neighboring Ti and occupied its site, eventually pushing it to an interstitial position. The defect configurations after Ti recoils in $\mathrm{A}_{2} \mathrm{Ti}_{2} \mathrm{O}_{7}$ along [100] direction consisted of Asite cation vacancy, Ti interstitial and $\mathrm{A}_{\mathrm{Ti}}$ antisite. However, there were different types of defects in $\mathrm{Ce}_{2} \mathrm{Ti}_{2} \mathrm{O}_{7}$ and $\mathrm{La}_{2} \mathrm{Ti}_{2} \mathrm{O}_{7}$. For Ti recoils along the [100] direction in $\mathrm{Ce}_{2} \mathrm{Ti}_{2} \mathrm{O}_{7}$, the Ti PKA collided with its neighboring Ce and occupied its site, eventually pushing the Ce into an interstitial position. Therefore, $\mathrm{Ti}$ vacancy, $\mathrm{Ti}_{\mathrm{Ce}}$ antisite and $\mathrm{Ce}$ interstitial were observed after $\mathrm{Ti}$ displacement in $\mathrm{Ce}_{2} \mathrm{Ti}_{2} \mathrm{O}_{7}$. In $\mathrm{La}_{2} \mathrm{Ti}_{2} \mathrm{O}_{7}$, when the Ti PKA was displaced along the [100] direction, the Ti moved far away from its initial site to form a stable interstitial, while a secondary knock-on atom (SKA) La collided with an adjacent Ti and occupied its site displacing the Ti into an interstitial position. Thus, Ti Frenkel pairs, La vacancy, $\mathrm{La}_{\mathrm{Ti}}$ antisite and Ti interstitial were produced after Ti displacement along the [100] direction. For $\mathrm{O}_{48 f}$ and $\mathrm{O}_{8 b}$ displacement along [100], the $\mathrm{O}$ anion PKA moved far away from its original site and occupied an interstitial position, i.e. O Frenkel pairs were observed. Compared with the defect end states of $\mathrm{Gd}_{2} \mathrm{Ti}_{2} \mathrm{O}_{7}$ in previous studies, our results show excellent agreement with Devanathan's ${ }^{22}$ MD simulation and similarities of defect configuration with Wang's ${ }^{37}$ AIMD simulation. Along [100], cation

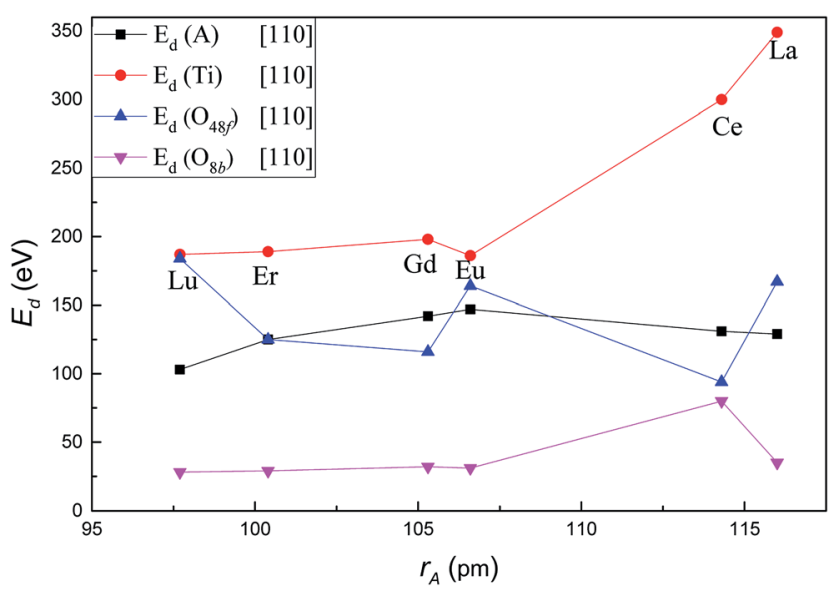

Fig. 3 Variation of $E_{d}$ value for $\mathrm{A}, \mathrm{Ti}, \mathrm{O}_{48 f}$ and $\mathrm{O}_{8 b}$ in $\mathrm{A}_{2} \mathrm{Ti}_{2} \mathrm{O}_{7}$ as a function of $\mathrm{A}$-site cation ionic radii along [110] crystallographic direction. displacements produced vacancies, interstitials and antisite defects on the cation sublattice, and anion displacements produced anion Frenkel pairs. These results are in excellent agreement with the type of defects observed after low-energy recoils by Chartier ${ }^{29}$ and Devanathan ${ }^{22}$ in pyrochlores.

\section{2 $E_{\mathrm{d}}$ in $\mathrm{A}_{2} \mathrm{Ti}_{2} \mathrm{O}_{7}$ pyrochlores along the [110] direction}

Fig. 3 shows the variation of $E_{\mathrm{d}}$ for each type of atom in titanate pyrochlores with increasing A-site cation radius along the crystallographic direction [110]. The values of $E_{\mathrm{d}}$ for each type of ion in titanate pyrochlores show much more variation with increasing cation radius for recoils along [110] direction than along [100]. The $E_{\mathrm{d}}$ of the A-site cation increased from $103 \mathrm{eV}$ in $\mathrm{Lu}_{2} \mathrm{Ti}_{2} \mathrm{O}_{7}$ to $147 \mathrm{eV}$ in $\mathrm{Eu}_{2} \mathrm{Ti}_{2} \mathrm{O}_{7}$, then decreased slightly to $129 \mathrm{eV}$ in $\mathrm{La}_{2} \mathrm{Ti}_{2} \mathrm{O}_{7}$. These values are much higher than the corresponding values for the [100] direction. The $E_{\mathrm{d}}$ of $\mathrm{Ti}$ increased considerably from $187 \mathrm{eV}$ in $\mathrm{Lu}_{2} \mathrm{Ti}_{2} \mathrm{O}_{7}$ to $349 \mathrm{eV}$ in $\mathrm{La}_{2} \mathrm{Ti}_{2} \mathrm{O}_{7}$. The $E_{\mathrm{d}}$ of $\mathrm{O}_{48 f}$ showed fluctuations with increasing Asite cation size, i.e. the $E_{\mathrm{d}}$ of $\mathrm{O}_{48 f}$ decreased from $184 \mathrm{eV}$ in $\mathrm{Lu}_{2} \mathrm{Ti}_{2} \mathrm{O}_{7}$ to $116 \mathrm{eV}$ in $\mathrm{Gd}_{2} \mathrm{Ti}_{2} \mathrm{O}_{7}$, then increased to $164 \mathrm{eV}$ in $\mathrm{Eu}_{2} \mathrm{Ti}_{2} \mathrm{O}_{7}$, dropped abruptly to $94 \mathrm{eV}$ in $\mathrm{Ce}_{2} \mathrm{Ti}_{2} \mathrm{O}_{7}$, and finally increased to $167 \mathrm{eV}$ in $\mathrm{La}_{2} \mathrm{Ti}_{2} \mathrm{O}_{7}$. The $E_{\mathrm{d}}$ of $\mathrm{O}_{8 b}$ was almost steady with a slight increase from $28 \mathrm{eV}$ in $\mathrm{Lu}_{2} \mathrm{Ti}_{2} \mathrm{O}_{7}$ to $35 \mathrm{eV}$ in $\mathrm{La}_{2} \mathrm{Ti}_{2} \mathrm{O}_{7}$, except for an increase to $80 \mathrm{eV}$ in $\mathrm{Ce}_{2} \mathrm{Ti}_{2} \mathrm{O}_{7}$. For displacements along the [110] direction, the $E_{\mathrm{d}}$ value for $\mathrm{O}_{48 f}$ was the smallest while the value for $\mathrm{O}_{8 b}$ was the largest in $\mathrm{Ce}_{2} \mathrm{Ti}_{2} \mathrm{O}_{7}$ among these titanate pyrochlores. Along [110], the value of $E_{\mathrm{d}}$ for the A cation was the highest and the value for $\mathrm{Ti}$ was the lowest in $\mathrm{Eu}_{2} \mathrm{Ti}_{2} \mathrm{O}_{7}$ among these titanate pyrochlores, which suggests that placing $\mathrm{Eu}$ in the A-site may cause an unusual radiation response compared to other $\mathrm{A}_{2} \mathrm{Ti}_{2} \mathrm{O}_{7}$ pyrochlores. In addition, the influence of A-site cation size on the variation of $E_{\mathrm{d}}$ for $\mathrm{Ti}$ and $\mathrm{O}_{48 \mathrm{f}}$ was larger than that for A-site cation and $\mathrm{O}_{8 b}$ in titanate pyrochlores along the [110] direction. With increasing A-site cation size, the variation trends of $E_{\mathrm{d}}$ along [110] for $\mathrm{Ti}$ in some titanate pyrochlores $\mathrm{A}_{2} \mathrm{Ti}_{2} \mathrm{O}_{7}$ $\left(\mathrm{A}=\mathrm{Lu}^{3+}, \mathrm{Er}^{3+}, \mathrm{Gd}^{3+}, \mathrm{Eu}^{3+}\right)$ was similar to the variation of the critical amorphization temperature $\left(T_{\mathrm{c}}\right)$, in Lian's ${ }^{\mathbf{1 3}}$ and Wang's ${ }^{20}$ experiments, while it is exactly the opposite of the trend in the critical amorphization dose $\left(D_{\mathrm{c}}\right)^{13}$ and structure parameter $(x){ }^{13}$ Therefore, the lower the $E_{\mathrm{d}}$ value of $\mathrm{Ti}$ in the titanate pyrochlore, the lower is the value of the $T_{\mathrm{c}}$, the higher is the $D_{\mathrm{c}}$ and $x$, the greater is the amorphization resistance, and the

Table 2 Surviving defects after displacements for each type of atom in titanate pyrochlore along [110]

\begin{tabular}{|c|c|c|c|c|}
\hline & A & $\mathrm{Ti}$ & $\mathrm{O}_{48 f}$ & $\mathrm{O}_{8 b}$ \\
\hline Name & Defects & Defects & Defects & Defects \\
\hline $\mathrm{Lu}_{2} \mathrm{Ti}_{2} \mathrm{O}_{7}$ & $\mathrm{~V}_{\mathrm{Lu}} \mathrm{Lu}_{\mathrm{i}} \mathrm{Lu}_{\mathrm{Ti}} \mathrm{Ti}_{\mathrm{iLu}}$ & $\mathrm{V}_{\mathrm{Ti}} \mathrm{Ti}_{\mathrm{i}} 2 \mathrm{~V}_{\mathrm{O}} 2 \mathrm{O}_{\mathrm{i}}$ & $\mathrm{V}_{\mathrm{O}} \mathrm{O}_{\mathrm{i}}$ & $\mathrm{V}_{\mathrm{O}} \mathrm{O}_{\mathrm{i}}$ \\
\hline $\mathrm{Er}_{2} \mathrm{Ti}_{2} \mathrm{O}_{7}$ & $\mathrm{~V}_{\mathrm{Er}} \mathrm{Ti}_{\mathrm{i}} 2 \mathrm{Er}_{\mathrm{Ti}} \mathrm{Ti}_{\mathrm{Er}}$ & $\mathrm{V}_{\mathrm{Ti}} \mathrm{Ti}_{\mathrm{i}} 3 \mathrm{~V}_{\mathrm{O}} 3 \mathrm{O}_{\mathrm{i}}$ & $\mathrm{V}_{\mathrm{O}} \mathrm{O}_{\mathrm{i}}$ & $\mathrm{V}_{\mathrm{O}} \mathrm{O}_{\mathrm{i}}$ \\
\hline $\mathrm{Gd}_{2} \mathrm{Ti}_{2} \mathrm{O}_{7}$ & $\mathrm{~V}_{\mathrm{Gd}} \mathrm{Ti}_{\mathrm{i}} 2 \mathrm{Gd}_{\mathrm{Ti}} \mathrm{Ti}_{\mathrm{Gd}}$ & $\mathrm{V}_{\mathrm{Ti}} \mathrm{Ti}_{\mathrm{i}} \mathrm{V}_{\mathrm{O}} \mathrm{O}_{\mathrm{i}}$ & $\mathrm{V}_{\mathrm{O}} \mathrm{O}_{\mathrm{i}}$ & $\mathrm{V}_{\mathrm{O}} \mathrm{O}_{\mathrm{i}}$ \\
\hline $\mathrm{Eu}_{2} \mathrm{Ti}_{2} \mathrm{O}_{7}$ & $\mathrm{~V}_{\mathrm{Eu}} \mathrm{Ti}_{\mathrm{i}} 2 \mathrm{Eu}_{\mathrm{Ti}} \mathrm{Ti}_{\mathrm{Eu}}$ & $\mathrm{V}_{\mathrm{Ti}} \mathrm{Ti}_{\mathrm{i}} 2 \mathrm{~V}_{\mathrm{O}} 2 \mathrm{O}_{\mathrm{i}}$ & $\mathrm{V}_{\mathrm{O}} \mathrm{O}_{\mathrm{i}}$ & $\mathrm{V}_{\mathrm{O}} \mathrm{O}_{\mathrm{i}}$ \\
\hline $\mathrm{Ce}_{2} \mathrm{Ti}_{2} \mathrm{O}_{7}$ & $\mathrm{~V}_{\mathrm{Ce}} \mathrm{Ti}_{\mathrm{i}} 2 \mathrm{Ce}_{\mathrm{Ti}} \mathrm{Ti}_{\mathrm{Ce}}$ & $\mathrm{Ce}_{\mathrm{Ti}} \mathrm{Ti}_{\mathrm{Ce}}$ & $\mathrm{V}_{\mathrm{O}} \mathrm{O}_{\mathrm{i}}$ & $\mathrm{V}_{\mathrm{O}} \mathrm{O}_{\mathrm{i}}$ \\
\hline $\mathrm{La}_{2} \mathrm{Ti}_{2} \mathrm{O}_{7}$ & $\mathrm{~V}_{\mathrm{La}} \mathrm{Ti}_{\mathrm{i}} 2 \mathrm{La}_{\mathrm{Ti}} \mathrm{Ti}_{\mathrm{La}}$ & $\mathrm{V}_{\mathrm{Ti}} \mathrm{Ti}_{\mathrm{i}} 2 \mathrm{~V}_{\mathrm{O}} 2 \mathrm{O}_{\mathrm{i}}$ & $\mathrm{V}_{\mathrm{O}} \mathrm{O}_{\mathrm{i}}$ & $\mathrm{V}_{\mathrm{O}} \mathrm{O}_{\mathrm{i}}$ \\
\hline
\end{tabular}


easier it is for the order-disorder transition. However, the variation of $E_{\mathrm{d}}$ for $\mathrm{O}_{48 f}$ was just the opposite. The displacement of Ti and $\mathrm{O}_{48 f}$ may play an important role in the amorphization resistance of certain titanate pyrochlores following low energy recoils.

Table 2 presents a summary of defects for each type of atom in titanate pyrochlores after low-energy recoils along [110] direction. For A-site cation displacements along [110] in titanate pyrochlores, the A-site cation PKA initially collided with a Ti atom nearby and replaced it, then the replaced Ti kept moving and occupied a neighboring A-site cation (denoted as the third knock-on atom, TKA). Eventually the A-site cation TKA occupied an adjacent Ti and displaced it into an interstitial position. This displacement process resulted in the production of a complex defect cluster consisting of A-site cation vacancy, $\mathrm{A}_{\mathrm{Ti}}$ antisite, $\mathrm{Ti}_{\mathrm{A}}$ antisite, and Ti interstitial. Otherwise, the type of defects after A-site cation recoils in $\mathrm{Lu}_{2} \mathrm{Ti}_{2} \mathrm{O}_{7}$ was different from that in other titanate pyrochlores, i.e. the Lu PKA left its original site and occupied the Ti-site forming $\mathrm{Lu}_{\mathrm{Ti}}$ antisite; the replaced $\mathrm{Ti}$ occupied a nearby Lu site and eventually pushed the Lu into an interstitial position. Such a displacement along the [110] resulted in the production of defects consisting of Lu vacancy, antisites of $\mathrm{Lu}_{\mathrm{Ti}}$ and $\mathrm{Ti}_{\mathrm{Lu}}$, and $\mathrm{Lu}$ interstitial. Because of the longer distance of the displacement collision process and the larger number of created defects, the $E_{\mathrm{d}}$ for A-site cation along [110] direction was higher compared to that along [100] direction. For Ti PKA along [110], Ti moved far away from its lattice site and occupied an interstitial position forming Ti Frenkel pairs, and one or more adjacent O-anions were also displaced off site forming anion Frenkel pairs. The number of anion Frenkel pairs depended heavily on the species of A-site cation. For example, there were three anion Frenkel pairs in $\mathrm{Er}_{2} \mathrm{Ti}_{2} \mathrm{O}_{7}$, while there was only one in $\mathrm{Gd}_{2} \mathrm{Ti}_{2} \mathrm{O}_{7}$. However, for $\mathrm{Ti}$ displacement along [110] direction in $\mathrm{Ce}_{2} \mathrm{Ti}_{2} \mathrm{O}_{7}$, only cation antisites of $\mathrm{Ce}_{\mathrm{Ti}}$ and $\mathrm{Ti}_{\mathrm{Ce}}$ are produced when the knock-on kinetic energy reached up to $300 \mathrm{eV}$. If Ce is substituted on the A-site of titanate pyrochlore, the amorphization susceptibility may be decreased, because the incident energy is

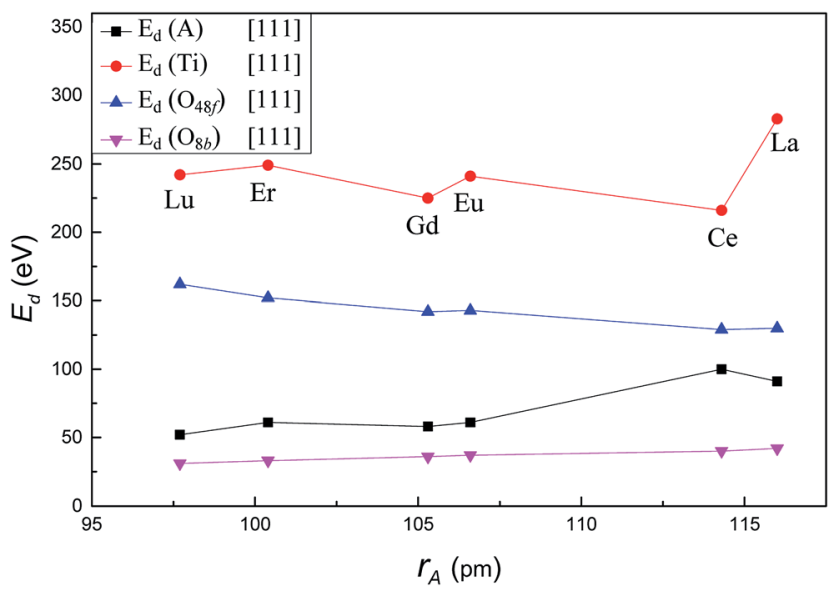

Fig. 4 Variation of $E_{d}$ value for $\mathrm{A}, \mathrm{Ti}, \mathrm{O}_{48 f}$ and $\mathrm{O}_{8 b}$ in $\mathrm{A}_{2} \mathrm{Ti}_{2} \mathrm{O}_{7}$ as a function of A-site cation ionic radii along [111] crystallographic direction. dissipated by formation of cation anti-site defects, which are high energy defects in $\mathrm{Ce}_{2} \mathrm{Ti}_{2} \mathrm{O}_{7}$. Similar to the case of the [100] direction, only anion Frenkel pairs were created by anion displacement along the [110] direction in all the titanate pyrochlores studied. Compared with the defect configurations of titanate pyrochlores after low-energies recoils events in previous studies $^{22,35-37}$ along [110], our results are consistent with classical MD simulation of Devanathan et al. ${ }^{22}$ The Ti-bridge and Tidumbbell which are considered as the stable configuration in the AIMD calculations of Wang et al. ${ }^{37}$ and Xiao et al. ${ }^{35}$ were not found in this work, which may be an indication of the limitation of empirical potentials.

\section{3 $E_{\mathrm{d}}$ in $\mathrm{A}_{2} \mathrm{Ti}_{2} \mathrm{O}_{7}$ pyrochlores along [111] direction}

Fig. 4 presents the variation of $E_{\mathrm{d}}$ for each atom type as a function of A-site cation radius along the crystallographic direction [111]. With increasing A-site cation radius, the $E_{\mathrm{d}}$ of A-site cation increased from $52 \mathrm{eV}$ in $\mathrm{Lu}_{2} \mathrm{Ti}_{2} \mathrm{O}_{7}$ to $91 \mathrm{eV}$ in $\mathrm{La}_{2} \mathrm{Ti}_{2} \mathrm{O}_{7}$, the $E_{\mathrm{d}}$ of Ti increased significantly from $242 \mathrm{eV}$ in $\mathrm{Lu}_{2} \mathrm{Ti}_{2} \mathrm{O}_{7}$ to $283 \mathrm{eV}$ in $\mathrm{La}_{2} \mathrm{Ti}_{2} \mathrm{O}_{7}$. However, the value for $\mathrm{O}_{48 f}$ decreased from $162 \mathrm{eV}$ in $\mathrm{Lu}_{2} \mathrm{Ti}_{2} \mathrm{O}_{7}$ to $130 \mathrm{eV}$ in $\mathrm{La}_{2} \mathrm{Ti}_{2} \mathrm{O}_{7}$. The $E_{\mathrm{d}}$ of $\mathrm{O}_{8 b}$ increased slightly from $31 \mathrm{eV}$ in $\mathrm{Lu}_{2} \mathrm{Ti}_{2} \mathrm{O}_{7}$ to $42 \mathrm{eV}$ in $\mathrm{Lu}_{2} \mathrm{Ti}_{2} \mathrm{O}_{7}$. It is important to note that among six different titanate pyrochlores, $E_{\mathrm{d}}$ for A-site cation was the largest (100 eV) and $E_{\mathrm{d}}$ for Ti was the smallest $(216 \mathrm{eV})$ when $\mathrm{Ce}$ is used as the A-site cation. That is to say, among these compounds, Ti was the most easily displaced in $\mathrm{Ce}_{2} \mathrm{Ti}_{2} \mathrm{O}_{7}$, while A-site cation was the least easily displaced, for PKA recoil along [111]. The result suggests that $\mathrm{Ce}_{2} \mathrm{Ti}_{2} \mathrm{O}_{7}$ may exhibit a different radiation resistance compared to other titanate pyrochlores. Compared with the previous studies, the $E_{\mathrm{d}}$ value of each atom in $\mathrm{Gd}_{2} \mathrm{Ti}_{2} \mathrm{O}_{7}$ is in good agreement with previous MD results, ${ }^{22}$ while significantly higher than Wang's ${ }^{37}$ AIMD results. The reason is that the charge transfer is ignored in the MD calculation as explained by Wang et al. ${ }^{37}$ Similar to the zirconate pyrochlores, ${ }^{23} \mathrm{~A}-$ site cation also has an important effect on the $E_{\mathrm{d}}$ of all atom types in titanate pyrochlores. Besides, it is easier to displace A-site cation than $\mathrm{Ti}^{4+}$, thus it requires less energy to displace A-site cation than $\mathrm{Ti}^{4+}$ in titanate pyrochlore which is consistent with the previous studies. ${ }^{22,35-37}$

Table 3 summarizes the defects produced by displacement events for each type of atom in titanate pyrochlores along the crystal direction [111]. In most of the titanate pyrochlores

Table 3 Surviving defects after displacements for each type of atom in titanate pyrochlore along [111]

\begin{tabular}{|c|c|c|c|c|}
\hline & $\mathrm{A}$ & $\mathrm{Ti}$ & $\mathrm{O}_{48 \mathrm{f}}$ & $\mathrm{O}_{8 \mathrm{~b}}$ \\
\hline Name & Defects & Defects & Defects & Defects \\
\hline $\mathrm{Lu}_{2} \mathrm{Ti}_{2} \mathrm{O}_{7}$ & $\mathrm{~V}_{\mathrm{Lu}} \mathrm{Lu}_{\mathrm{i}}$ & $\mathrm{V}_{\mathrm{Ti}} \mathrm{Ti}_{\mathrm{i}}$ & $\mathrm{V}_{\mathrm{O}} \mathrm{O}_{\mathrm{i}}$ & $\mathrm{V}_{\mathrm{O}} \mathrm{O}_{\mathrm{i}}$ \\
\hline $\mathrm{Er}_{2} \mathrm{Ti}_{2} \mathrm{O}_{7}$ & $\mathrm{~V}_{\mathrm{Er}} \mathrm{Er}_{\mathrm{i}}$ & $\mathrm{V}_{\mathrm{Ti}} \mathrm{Ti}_{\mathrm{i}}$ & $\mathrm{V}_{\mathrm{O}} \mathrm{O}_{\mathrm{i}}$ & $\mathrm{V}_{\mathrm{O}} \mathrm{O}_{\mathrm{i}}$ \\
\hline $\mathrm{Gd}_{2} \mathrm{Ti}_{2} \mathrm{O}_{7}$ & $\mathrm{~V}_{\mathrm{Gd}} \mathrm{Gd}_{\mathrm{i}}$ & $\mathrm{Ti}_{\mathrm{Gd}} \mathrm{Gd}_{\mathrm{Ti}}$ & $\mathrm{V}_{\mathrm{O}} \mathrm{O}_{\mathrm{i}}$ & $\mathrm{V}_{\mathrm{O}} \mathrm{O}_{\mathrm{i}}$ \\
\hline $\mathrm{Eu}_{2} \mathrm{Ti}_{2} \mathrm{O}_{7}$ & $\mathrm{~V}_{\mathrm{Eu}} \mathrm{Eu}_{\mathrm{i}}$ & $\mathrm{Eu}_{\mathrm{Ti}} \mathrm{Ti}_{\mathrm{Eu}}$ & $\mathrm{V}_{\mathrm{O}} \mathrm{O}_{\mathrm{i}}$ & $\mathrm{V}_{\mathrm{O}} \mathrm{O}_{\mathrm{i}}$ \\
\hline $\mathrm{Ce}_{2} \mathrm{Ti}_{2} \mathrm{O}_{7}$ & 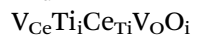 & $\mathrm{Ce}_{\mathrm{Ti}} \mathrm{Ti}_{\mathrm{Ce}} \mathrm{V}_{\mathrm{O}} \mathrm{O}_{\mathrm{i}}$ & $\mathrm{V}_{\mathrm{O}} \mathrm{O}_{\mathrm{i}}$ & $\mathrm{V}_{\mathrm{O}} \mathrm{O}_{\mathrm{i}}$ \\
\hline $\mathrm{La}_{2} \mathrm{Ti}_{2} \mathrm{O}_{7}$ & $\mathrm{~V}_{\mathrm{La}} \mathrm{Ti}_{\mathrm{i}} \mathrm{La}_{\mathrm{Ti}}$ & $\mathrm{V}_{\mathrm{La}} \mathrm{Ti}_{\mathrm{i}} \mathrm{La}_{\mathrm{Ti}} \mathrm{V}_{\mathrm{O}} \mathrm{O}_{\mathrm{i}}$ & $\mathrm{V}_{\mathrm{O}} \mathrm{O}_{\mathrm{i}}$ & $\mathrm{V}_{\mathrm{O}} \mathrm{O}_{\mathrm{i}}$ \\
\hline
\end{tabular}


Table 4 The minimum value of $E_{\mathrm{d}}$ and corresponding directions for each type of ions in titanate pyrochlores

\begin{tabular}{|c|c|c|c|c|c|c|c|c|}
\hline \multirow[b]{2}{*}{ Name } & \multicolumn{2}{|l|}{$\mathrm{A}^{3+}$} & \multicolumn{2}{|l|}{$\mathrm{Ti}^{4+}$} & \multicolumn{2}{|l|}{$\mathrm{O}_{48 f}$} & \multicolumn{2}{|l|}{$\mathrm{O}_{8 b}$} \\
\hline & $E_{\mathrm{d}}(\mathrm{eV})$ & Direction & $E_{\mathrm{d}}(\mathrm{eV})$ & Direction & $E_{\mathrm{d}}(\mathrm{eV})$ & Direction & $E_{\mathrm{d}}(\mathrm{eV})$ & Direction \\
\hline $\mathrm{Er}_{2} \mathrm{Ti}_{2} \mathrm{O}_{7}$ & 61 & {$[111]$} & 154 & {$[100]$} & 53 & {$[100]$} & 29 & [110] \\
\hline $\mathrm{Gd}_{2} \mathrm{Ti}_{2} \mathrm{O}_{7}$ & 58 & {$[111]$} & 147 & {$[100]$} & 53 & {$[100]$} & 32 & {$[110]$} \\
\hline $\mathrm{Eu}_{2} \mathrm{Ti}_{2} \mathrm{O}_{7}$ & 61 & [111] & 146 & {$[100]$} & 53 & {$[100]$} & 31 & [110] \\
\hline
\end{tabular}

$\left(\mathrm{A}_{2} \mathrm{Ti}_{2} \mathrm{O}_{7}, \mathrm{~A}=\mathrm{Lu}^{3+}, \mathrm{Er}^{3+}, \mathrm{Gd}^{3+}, \mathrm{Eu}^{3+}\right)$, the A-site cation PKA moved far away from its initial site along this direction and occupied an interstitial position, forming an A-site cation Frenkel pair defect. It is worth noting that, after Ce displacements in $\mathrm{Ce}_{2} \mathrm{Ti}_{2} \mathrm{O}_{7}$ along [111], the Ce PKA moved far away from its equilibrium site and collided with a Ti atom to replace this atom, finally pushing the $\mathrm{Ti}$ into an interstitial position. Meantime, the nearby $\mathrm{O}$ was displaced from its original site resulting in an anion Frenkel pair. Therefore, A-site cation vacancy, $\mathrm{A}_{\mathrm{Ti}}$ antisite, Ti interstitial and anion Frenkel pairs were produced. The value of $E_{\mathrm{d}}$ for Ce is the highest among these titanate pyrochlores because Ce PKA produced the largest number of defects, including defects on both cation and anion sublattices. Similarly, the defects after La displacements in $\mathrm{La}_{2} \mathrm{Ti}_{2} \mathrm{O}_{7}$ consisted of A-site cation vacancy, $\mathrm{A}_{\mathrm{Ti}}$ antisite and Ti interstitial. For Ti displacement along [111], Ti Frenkel pairs were produced in $\mathrm{Lu}_{2} \mathrm{Ti}_{2} \mathrm{O}_{7}$ and $\mathrm{Er}_{2} \mathrm{Ti}_{2} \mathrm{O}_{7}$, while antisites of $\mathrm{Ti}_{\mathrm{A}}$ and $\mathrm{A}_{\mathrm{Ti}}$ were observed in $\mathrm{Gd}_{2} \mathrm{Ti}_{2} \mathrm{O}_{7}, \mathrm{Eu}_{2} \mathrm{Ti}_{2} \mathrm{O}_{7}$ and $\mathrm{Ce}_{2} \mathrm{Ti}_{2} \mathrm{O}_{7}$, and anion Frenkel pairs were also generated in $\mathrm{Ce}_{2} \mathrm{Ti}_{2} \mathrm{O}_{7}$. However, when $\mathrm{Ti}$ was displaced along [111] in $\mathrm{La}_{2} \mathrm{Ti}_{2} \mathrm{O}_{7}$, the Ti PKA returned to its site, after displacing an adjacent La off its site. The SKA La collided with a neighboring Ti and replaced the Ti atom, finally pushing the Ti into an interstitial position. Simultaneously, a neighboring $\mathrm{O}$ was pushed far away from its site, forming an anion Frenkel pair. Thus, A-site cation vacancies, $\mathrm{La}_{\mathrm{Ti}}$ antisite, $\mathrm{Ti}$ interstitials, and $\mathrm{O}$ Frenkel pairs were produced after Ti low-energy recoils along [111] direction. The highest $E_{\mathrm{d}}$ for Ti was observed in $\mathrm{La}_{2} \mathrm{Ti}_{2} \mathrm{O}_{7}$ among the titanate pyrochlores and the largest number of defects was produced after $\mathrm{Ti}$ displacement in the material. For the O-anion displacements along [111], we only observed anion Frenkel pairs, which is the same result as in the case of PKA directions [100] and [110]. For the anion low-energy displacement recoils, our results show excellent agreement with the previous studies. ${ }^{23,37}$ However, the defect end states of Gd and Ti along [111] are in good agreement with MD results of Devanathan et al. ${ }^{22}$ and AIMD results of Wang et al. ${ }^{37}$

\subsection{The minimum and average value of $E_{\mathrm{d}}$ in $\mathrm{A}_{2} \mathrm{Ti}_{2} \mathrm{O}_{7}$ pyrochlores}

Table 4 lists the minimum value of $E_{\mathrm{d}}$ and corresponding directions for each type of ions in titanate pyrochlores. Among these three directions, the easiest displacement directions for $\mathrm{Ti}^{4+}$ and $\mathrm{O}_{48 f}$ is along [100], however, the corresponding
Table 5 The average value of $E_{\mathrm{d}}$ for each sublattice in titanate pyrochlores

\begin{tabular}{|c|c|c|c|}
\hline & $\mathrm{A}^{3+}$ & $\mathrm{Ti}^{4+}$ & $\mathrm{O}^{2-}$ \\
\hline Name & $E_{\mathrm{d}}(\mathrm{eV})$ & $E_{\mathrm{d}}(\mathrm{eV})$ & $E_{\mathrm{d}}(\mathrm{eV})$ \\
\hline $\mathrm{Lu}_{2} \mathrm{Ti}_{2} \mathrm{O}_{7}$ & 75 & 200 & 85 \\
\hline $\mathrm{Er}_{2} \mathrm{Ti}_{2} \mathrm{O}_{7}$ & 85 & 197 & 75 \\
\hline $\mathrm{Gd}_{2} \mathrm{Ti}_{2} \mathrm{O}_{7}$ & 89 & 190 & 72 \\
\hline $\mathrm{Eu}_{2} \mathrm{Ti}_{2} \mathrm{O}_{7}$ & 92 & 191 & 80 \\
\hline $\mathrm{Ce}_{2} \mathrm{Ti}_{2} \mathrm{O}_{7}$ & 97 & 217 & 76 \\
\hline $\mathrm{La}_{2} \mathrm{Ti}_{2} \mathrm{O}_{7}$ & 97 & 256 & 80 \\
\hline
\end{tabular}

directions for $\mathrm{A}^{3+}$ and $\mathrm{O}_{8 b}$ in titanate pyrochlores depended on the A-site cation size. The $\mathrm{A}^{3+}$ can be displaced at energies from $52 \mathrm{eV}$ to $71 \mathrm{eV}$, while Ti can be displaced at energies ranged from 134 to $172 \mathrm{eV}$. Based on the minimum value of value of $E_{\mathrm{d}}$, to displace $\mathrm{A}^{3+}$ required less energy than to displace $\mathrm{Ti}^{4+}$ cation, which is in good agreement with previous studies. ${ }^{22,35-37}$ The minimum value of $E_{\mathrm{d}}$ for $\mathrm{O}_{48 f}$ and $\mathrm{O}_{8 b}$ in titanate pyrochlore is around $53 \mathrm{eV}$ and $35 \mathrm{eV}$, respectively, which is in excellent agreement with the results of $(47 \pm 5) \mathrm{eV}$ for $\mathrm{O}$ in $\mathrm{La}_{2} \mathrm{Zr}_{2} \mathrm{O}_{7}$ pyrochlore examined experimentally by Smith et al. ${ }^{28}$ The smallest value of $E_{\mathrm{d}}$ for each type of ion in titanate pyrochlores varies considerably with A-site cation.

In addition, the average value of $E_{\mathrm{d}}$ for each sublattice in titanate pyrochlores is listed in Table 5 , which can be used as input for TRIM and SRIM.

\section{Conclusions}

The $E_{\mathrm{d}}$ value and defect configurations after low-energy displacements for each type of atom in titanate pyrochlores $\mathrm{A}_{2} \mathrm{Ti}_{2} \mathrm{O}_{7}\left(\mathrm{~A}=\mathrm{Lu}^{3+}, \mathrm{Er}^{3+}, \mathrm{Gd}^{3+}, \mathrm{Eu}^{3+}, \mathrm{Ce}^{3+}, \mathrm{La}^{3+}\right)$ along [100], [110] and [111] crystallographic direction have been investigated by the classical molecular dynamics method. The main conclusions are as follows.

(i) The value of $E_{\mathrm{d}}$ for each type of ion in titanate pyrochlores varies with the A-site cation composition. The influence of A-site cation radius on the value of $E_{\mathrm{d}}$ for $\mathrm{Ti}$ and $\mathrm{O}_{48 f}$ was much larger than that for $\mathrm{A}$ and $\mathrm{O}_{8 b}$ in titanate pyrochlore. $E_{\mathrm{d}}$ depended on knock-on direction, ion type, and Wyckoff position (48f and 8b for O). Besides, the value of $E_{\mathrm{d}}$ for each type of atom in titanate pyrochlore was highly anisotropic. The largest change of $E_{\mathrm{d}}$ was for $\mathrm{Ti}$, while the smallest change of $E_{\mathrm{d}}$ was for $\mathrm{O}_{8 b}$. With 
increasing A-site cation radius, the $E_{\mathrm{d}}$ value for $\mathrm{Ti}^{4+}$ cations in titanate pyrochlores along the [100] direction decreased steadily, while it generally increased along [110]. The $E_{\mathrm{d}}$ value for $\mathrm{O}_{48 f}$ decreased considerably with increasing A-site cation radius along [111]. $E_{\mathrm{d}}$ for $\mathrm{O}_{8 b}$ was almost stable at about $(55 \pm 2) \mathrm{eV},(31 \pm 4) \mathrm{eV}$, and $(37 \pm 6) \mathrm{eV}$ along [100], [110] and [111], respectively. Other $E_{\mathrm{d}}$ values did not show clear monotonic trends.

(ii) Along the [110] direction, in some $\mathrm{A}_{2} \mathrm{Ti}_{2} \mathrm{O}_{7}$ pyrochlores $\left(\mathrm{A}=\mathrm{Lu}^{3+}, \mathrm{Er}^{3+}, \mathrm{Gd}^{3+}, \mathrm{Eu}^{3+}\right)$, the $E_{\mathrm{d}}$ variation of $\mathrm{Ti}$ as a function of A-site cation radius followed a similar trend as the critical amorphization temperature $\left(T_{\mathrm{c}}\right)$ in previous experiments. It was found that the higher the value of $E_{\mathrm{d}}$, the higher the critical amorphization temperature $\left(T_{\mathrm{c}}\right)$, and the weaker the amorphization resistance. Ti displacements along [110] may play a key role in the amorphization tolerance of titanate pyrochlores. Among these four materials, $\mathrm{Gd}_{2} \mathrm{Ti}_{2} \mathrm{O}_{7}$ exhibited the highest $E_{\mathrm{d}}$ for $\mathrm{Ti}$ along [110] of about $200 \mathrm{eV}$, which is correlated with $\mathrm{Gd}_{2} \mathrm{Ti}_{2} \mathrm{O}_{7}$ being the most susceptible to amorphization.

(iii) Based on the minimum value of $E_{\mathrm{d}}$, it required less energy to displace the $\mathrm{A}^{3+}$ cation than the $\mathrm{Ti}^{4+}$ cation. The former had displacement energies from 52 to $71 \mathrm{eV}$, while the corresponding values for the latter ranged from 134 to $171 \mathrm{eV}$. Anions could be displaced at energies around $30 \mathrm{eV}$. Although our displacement energies from MD are significantly higher than Wang's AIMD results, ${ }^{37}$ both the methods exhibit some similar behavior in the mechanisms of defect creation and defect configuration.

(iv) The smallest $E_{\mathrm{d}}$ for each type of atom in every titanate pyrochlore occurred along different crystallographic directions. The easiest displacement direction for $\mathrm{Ti}^{4+}$ and $\mathrm{O}_{48 f}$ was along [100], while the corresponding directions for $\mathrm{A}^{3+}$ and $\mathrm{O}_{8 b}$ in titanate pyrochlores depended on the A-site cation size.

(v) The defects created after low-energy displacements consisted of cation interstitials and vacancies, cation antisite defects, and anion Frenkel-pairs. Among them, cation Frenkel pairs were dominant at the end of the low energy recoils. Both cation and anion defects were observed after cation displacements, while only anion defects were produced after anion displacements. Therefore, cation displacement, which occurs at higher energies, holds the key to amorphization resistance. For Ti recoils along [110], Ce and Ti ions exchanged sites to produce two antisite defects in $\mathrm{Ce}_{2} \mathrm{Ti}_{2} \mathrm{O}_{7}$ in contrast to the production of cation Frenkel pairs in other titanate pyrochlores. The formation of this high energy defect pair in $\mathrm{Ce}_{2} \mathrm{Ti}_{2} \mathrm{O}_{7}$ may make this particular titanate highly susceptible to amorphization.

\section{Acknowledgements}

L. Y. Dong wants to thank China Scholarship Council for supporting her study at the Pacific Northwest National Laboratory and University of Michigan. This work was supported by the National Natural Science Foundation of China (No. 11475076 and 11175076). F. Gao is supported by the award NRCHQ-13-G38-0007 from the US Nuclear Regulatory Commission. The statements, findings, conclusions, and recommendations are those of the authors and do not necessarily reflect the view of the US Nuclear Regulatory Commission.

\section{References}

1 R. Ewing, W. Weber and F. Clinard, Prog. Nucl. Energy, 1995, 29, 63-127.

2 R. C. Ewing, J. Appl. Phys., 2004, 95, 5949.

3 K. E. Sickafus, R. W. Grimes, J. A. Valdez, A. Cleave, M. Tang, M. Ishimaru, S. M. Corish, C. R. Stanek and B. P. Uberuaga, Nat. Mater., 2007, 6, 217-223.

4 W. J. Weber, R. C. Ewing, C. Catlow, T. D. De La Rubia, L. Hobbs, C. Kinoshita, H. Matzke, A. Motta, M. Nastasi and E. Salje, J. Mater. Res., 1998, 13, 1434-1484.

5 K. E. Sickafus, Science, 2000, 289, 748-751.

6 W. J. Weber and R. C. Ewing, Science, 2000, 289, 2051-2052. 7 A. Ringwood, S. Kesson, N. Ware, W. Hibberson and A. Major, Nature, 1979, 278, 219-223.

8 J. Lian, X. Zu, K. Kutty, J. Chen, L. Wang and R. Ewing, Phys. Rev. B: Condens. Matter Mater. Phys., 2002, 66, 054108.

9 J. Chen, J. Lian, L. M. Wang, R. C. Ewing and L. A. Boatner, Appl. Phys. Lett., 2001, 79, 1989.

10 K. B. Helean, S. V. Ushakov, C. E. Brown, A. Navrotsky, J. Lian, R. C. Ewing, J. M. Farmer and L. A. Boatner, J. Solid State Chem., 2004, 177, 1858-1866.

11 G. C. Lau, T. M. McQueen, Q. Huang, H. W. Zandbergen and R. J. Cava, J. Solid State Chem., 2008, 181, 45-50.

12 Y. H. Li, B. P. Uberuaga, C. Jiang, S. Choudhury, J. A. Valdez, M. K. Patel, J. Won, Y. Q. Wang, M. Tang and D. J. Safarik, Phys. Rev. Lett., 2012, 108, 195504.

13 J. Lian, J. Chen, L. M. Wang and R. C. Ewing, Phys. Rev. B: Condens. Matter Mater. Phys., 2003, 68, 134107.

14 J. Lian, L. M. Wang, R. C. Ewing and L. A. Boatner, Nucl. Instrum. Methods Phys. Res., Sect. B, 2005, 241, 365-371.

15 F. X. Zhang and S. K. Saxena, Chem. Phys. Lett., 2005, 413, 248-251.

16 S. X. Wang, B. D. Begg, L. M. Wang, R. C. Ewing, W. J. Weber and K. Kutty, J. Mater. Res., 1999, 14, 4470-4473.

17 R. Devanathan, F. Gao and C. J. Sundgren, $R S C A d v ., 2013,3$, 2901-2909.

18 L. Minervini, R. W. Grimes and K. E. Sickafus, J. Am. Ceram. Soc., 2000, 83, 1873-1878.

19 J. Lian, R. C. Ewing, L. M. Wang and K. B. Helean, J. Mater. Res., 2011, 19, 1575-1580.

20 S. Wang, L. Wang, R. Ewing and K. G. Kutty, Nucl. Instrum. Methods Phys. Res., Sect. B, 2000, 169, 135-140.

21 B. D. Begg, N. J. Hess, W. J. Weber, R. Devanathan, J. P. Icenhower, S. Thevuthasan and B. P. McGrail, J. Nucl. Mater., 2001, 288, 208-216.

22 R. Devanathan and W. J. Weber, J. Appl. Phys., 2005, 98, 086110.

23 H. Y. Xiao, W. J. Weber, Y. Zhang and X. T. Zu, Acta Mater., 2015, 87, 273-282.

24 R. Williford, R. Devanathan and W. Weber, Nucl. Instrum. Methods Phys. Res., Sect. B, 1998, 141, 94-98.

25 S. J. Zinkle and C. Kinoshita, J. Nucl. Mater., 1997, 251, 200217. 
26 P. Agnew, Philos. Mag. A, 1992, 65, 355-361.

27 D. R. Locker and J. M. Meese, IEEE Trans. Nucl. Sci., 1972, 19, 237-242.

28 K. L. Smith, M. Colella, R. Cooper and E. R. Vance, J. Nucl. Mater., 2003, 321, 19-28.

29 A. Chartier, C. Meis, J. P. Crocombette, L. R. Corrales and W. J. Weber, Phys. Rev. B: Condens. Matter Mater. Phys., 2003, 67, 147102.

30 C. Erginsoy, G. H. Vineyard and A. Englert, Phys. Rev., 1964, 133, A595-A606.

31 K. Nordlund, J. Wallenius and L. Malerba, Nucl. Instrum. Methods Phys. Res., Sect. B, 2006, 246, 322-332.

32 N. Juslin, K. Nordlund, J. Wallenius and L. Malerba, Nucl. Instrum. Methods Phys. Res., Sect. B, 2007, 255, 75-77.

33 B. S. Thomas, N. A. Marks, L. R. Corrales and R. Devanathan, Nucl. Instrum. Methods Phys. Res., Sect. B, 2005, 239, 191-201.

34 P. A. F. P. Moreira, R. Devanathan, J. Yu and W. J. Weber, Nucl. Instrum. Methods Phys. Res., Sect. B, 2009, 267, 34313436.

35 H. Y. Xiao, F. Gao and W. J. Weber, J. Phys.: Condens. Matter, 2010, 22, 415801.
36 F. Gao, H. Y. Xiao and W. J. Weber, Nucl. Instrum. Methods Phys. Res., Sect. B, 2011, 269, 1693-1697.

37 X. J. Wang, H. Y. Xiao, X. T. Zu, Y. Zhang and W. J. Weber, J. Mater. Chem. C, 2013, 1, 1665-1673.

38 W. Möller and W. Eckstein, Nucl. Instrum. Methods Phys. Res., Sect. B, 1984, 2, 814-818.

39 J. F. Ziegler, M. D. Ziegler and J. P. Biersack, Nucl. Instrum. Methods Phys. Res., Sect. B, 2010, 268, 1818-1823.

40 M. Subramanian, G. Aravamudan and G. S. Rao, Prog. Solid State Chem., 1983, 15, 55-143.

41 U. Essmann, L. Perera, M. L. Berkowitz, T. Darden, H. Lee and L. G. Pedersen, J. Chem. Phys., 1995, 103, 8577-8593.

42 L. Dong, Y. Li, R. Devanathan and F. Gao, RSC Adv., 2016, 6, 41410-41419.

43 S. Plimpton, J. Comput. Phys., 1995, 117, 1-19.

44 F. Gao and W. Weber, Phys. Rev. B: Condens. Matter Mater. Phys., 2002, 66, 024106.

45 L. Malerba, D. Terentyev, P. Olsson, R. Chakarova and J. Wallenius, J. Nucl. Mater., 2004, 329, 1156-1160.

46 Y. Zhang, M. Ishimaru, T. Varga, T. Oda, C. Hardiman, H. Xue, Y. Katoh, S. Shannon and W. J. Weber, Phys. Chem. Chem. Phys., 2012, 14, 13429-13436. 